\title{
Comment on the Article Published in Forest by Maria Fernanda Gebara and Arun Agrawal, Forests 2017, 8, 66
}

\author{
Erika P. P. Pinto *, Paulo Moutinho and Osvaldo Stella
}

Amazon Environmental Research Institute (IPAM), SHIN CA 5, Bloco J2, Sala 309, Bairro Lago Norte, Brasília DF 71503-505, Brazil; moutinho@ipam.org.br (P.M.); osvaldostella@ipam.org.br (O.S.)

* Correspondence: erika@ipam.org.br; Tel.: +55-61-999610550

Academic Editors: Esteve Corbera and Heike Schroeder

Received: 21 June 2017; Accepted: 22 June 2017; Published: 29 June 2017

The article entitled "Beyond Rewards and Punishments in the Brazilian Amazon: Practical Implications of the REDD+ Discourse" [1], published in the journal "Forests", provides an interesting analysis for evaluating the performance of payment for environmental services (PES) initiatives in the region. Among the initiatives selected by the authors was one called Sustainable Settlements, which is being implemented by the Amazon Environmental Research Institute (IPAM) in the Transamazon region in Brazil. In Table 2, the authors described various local perceptions on IPAM's PES project as a result of interviews made by the authors with the beneficiaries' families. While the methodology used by the authors to evaluate the performance of the listed projects seems appropriate, we are concerned that, in the case of IPAM's project, their results have been restricted by sampling bias. First, we know from previous discussions with the authors that the families selected for interviews were defined prior to IPAM's definition of who would receive PES during the project. As a consequence, only 35 of the 120 families interviewed by the authors effectively participated in IPAM's PES project. In this sense, given that roughly $70 \%$ of the interviewees were not part of the project, it is difficult to corroborate the "Local Perceptions" presented in Table 2. Furthermore, the authors comment on IPAM's PES project in Transamazon (p. 13), saying that "the initiative started implementing conditional payments in 2014, but there is no evidence yet of its outcomes". Thus, if there is no evidence of outcomes, and considering the mentioned sampling bias, we do not see evidence to support the local perceptions on IPAM's project as presented in Table 2. Contrary to what was expressed by the authors in Table 2 ("minimal financial resources being allocated to communities"), each beneficiary of IPAM's PES project have received additional and continuous technical assistance, financial investments for productive activities, support for participation in technical training events, support to strengthen productive supply chains, support for environmental regularization, among other benefits [2-4]. Lastly, the most recent monitoring results from IPAM's PES project (in 2015) indicated an increase of about $60 \%$ in the family's income for those participating in the project, along with an increment in terms of diversification of production when compared to a baseline scenario [5].

Final IPAM comments to the authors:

"We are grateful to the authors for the additional information about their study's results and objectives. However, we would like to make some extra comments based on their responses. Since the goal of this study is "presenting a discursive analysis of REDD+ in the Brazilian Amazon", we are not sure if this goal can be achieved given the fact that the rural family farmers interviewed have no idea about what REDD+ means. Furthermore, it is important to highlight that even those families who participate in IPAM's project (regarding that such families represent only $30 \%$ of the families interviewed by the authors) acknowledge the system for valuation of environmental services such 
as PSA (Payment for Environmental Services or Pagamento por Serviços Ambientais, in Portuguese), and not the term REDD+. In relation to the results presented in Table 2, there is no misreading as the author said: the authors conclusions based on the perceptions have led to a performance evaluation of the analyzed initiatives. This is clear in the article. In conclusion, it is our judgement that the authors clearly make an inference about the performance of the initiatives and the methodological problems previously cited persist".

\section{References}

1. Gebara, M.F.; Agrawal, A. Beyond Rewards and Punishments in the Brazilian Amazon: Practical Implications of the REDD+ Discourse. Forests 2017, 8, 66. [CrossRef]

2. Pinto, E.P.P. O papel do pagamento por serviços ambientais conforme a realidade de diferentes perfis de agricultores familiares da Amazônia. 2016. 138 f., il. Dissertação (Mestrado em Desenvolvimento Sustentável)—Universidade de Brasília, Brasília. Available online: http:/ / repositorio.unb.br/handle/10482/ 23022 (accessed on 11 May 2017).

3. Martins, O.S.; Moutinho, P.; Pinto, E.P.P.; Rettmann, R.; Mazer, S.; Xavier, G. Avoided Deforestation on Smallholder Farms in the Brazilian Amazon. In Climate Change Mitigation and Agriculture; Wollenberg, E., Nihart, A., Grieg-Gran, M., Tapio-Bistrom, M.-L., Eds.; Taylor \& Francis Books: London, UK; New York, NY, USA, 2013; pp. 181-192.

4. Stella, O.; Moutinho, P.; Pereira, C.; Souza, L.; Costa, R.; Cardoso, A.; Bentes, A.J.; Pinto, E.P.P.; Soave, M., Jr. Assentamentos Sustentáveis na Amazônia (PAS): Viabilizando Agricultura Familiar de Baixo Carbono. In Caminhos para uma Agricultura Familiar sob Bases Ecológicas: Produzindo com Baixa Emissão de Carbono; Azevedo, A., Campanili, M., Pereira, C., Eds.; IPAM: Brasília, Brazil, 2015; pp. 183-197.

5. IPAM Team. IPAM Technical Report to Amazon Fund, 2015; IPAM: Belém, Brazil, 2015; Copies of the report can be requested from the correspondent author.

(C) 2017 by the authors. Licensee MDPI, Basel, Switzerland. This article is an open access article distributed under the terms and conditions of the Creative Commons Attribution (CC BY) license (http://creativecommons.org/licenses/by/4.0/). 